\title{
Gambaran Mikroskopis Mycobacterium tuberculosis Pada Pasien Tuberkulosis di Puskesmas Kota Kaler Sumedang
}

\author{
*Imas Latifah ${ }^{1)}$, Yunia Qonitatin Al Masyani' ${ }^{2)}$, Prima Nanda Fauziah ${ }^{1)}$ \\ ${ }^{1}$ Prodi Analis Kesehatan, Fakultas Kesehatan, Universitas Mohammad Husni Thamrin, Jakarta \\ ${ }^{2}$ Puskesmas Kecamatan Cisarua Kabupaten Sumedang \\ *Correspodence author: Imas Latifah, imaslatifah72@gmail.com, Jakarta, Indonesia
}

\begin{abstract}
Abstrak
Tuberkulosis (TB) masih menjadi masalah utama kesehatan dunia yang bertanggung jawab terhadap kesehatan yang buruk bagi jutaan orang setiap tahunnya. Pada tahun 2018, jumlah kasus TB Indonesia berada di urutan ketiga terbesar dunia. Penelitian ini bertujuan untuk mengetahui gambaran mikroskopik Mycobacterium tuberculosis $(M t b)$ pada pasien yang sedang mengkonsumsi Obat Anti Tuberkulosis (OAT).Hasil penelitian menunjukan sebagian besar responden atau penderita TB positif yang melakukan pemeriksaan dengan hasil +1 sebanyak 19 orang (63, 3\%), sedangkan terendah scanty (1-9) dan negatif (-) tidak ada. Pasien TB yang telah melakukan pengobatan bulan ke II menunjukan sebagian besar pasien sudah negatif (-) sebanyak 26 pasien (86,7\%) sedangkan 4 pasien lainnya masih menunjukan hasil positif. Pasien TB yang telah melakukan pengobatan bulan ke V menunjukan semua pasien sudah negatif (-) sebanyak 30 pasien $(100 \%)$. Pasien TB yang telah melakukan pengobatan bulan ke VI menunjukan semua pasien sudah negatif (-) sebanyak 30 pasien (100\%). Dari hasil penelitian disimpulkan bahwa sebelum melakukan pengobatan dari ke 30 pasien positif TB menjadi negatif setelah melakukan pengobatan selama enam bulan. Oleh karena itu, diharapkan khususnya kepada pemerintah dan instansi yang terkait untuk lebih memperhatikan tugasnya dalam menunjang kepatuhan minum obat pada penderita TB.
\end{abstract}

Kata kunci $\quad$ : Mikroskopis, $M t b$, tuberkulosis

\begin{abstract}
Tuberculosis (TB) is still a major global health problem which is responsible for ill health for millions of people every year. In 2018, the number of TB cases in Indonesia was the third largest in the world. This study aims to determine the microscopic picture of Mycobacterium tuberculosis (Mtb) in patients who are currently taking antituberculosis drugs (OAT). The results showed that most of the respondents or positive TB patients who did the examination with a result of +1 as many as 19 people (63,3\%), while the lowest scanty (1-9) and negative (-) did not exist. TB patients who had undergone the second month of treatment showed that most of the patients were negative (-) as many as 26 patients (86.7\%) while 4 other patients still showed positive results. TB patients who have taken the fifth month of treatment showed that all patients were negative (-) as many as 30 patients (100\%). $T B$ patients who have taken the 6th month of treatment showed that all patients were negative (-) as many as 30 patients $(100 \%)$. From the results of the study, it was concluded that before treatment, 30 TB positive patients became negative after taking treatment for six months. Therefore, it is expected that the government and related agencies pay more attention to their duties in supporting compliance with taking medication in TB sufferers.
\end{abstract}

Keywords $\quad:$ Microscopic, Mtb, tuberculosis

Open Journal System (OJS): journal.thamrin.ac.id 


\section{PENDAHULUAN}

Tuberkulosis (TB) masih menjadi masalah utama kesehatan dunia yang bertanggung jawab terhadap kesehatan yang buruk bagi jutaan orang setiap tahunnya. Di seluruh dunia, TB menjadi penyebab kematian kedua terdepan penyakit menular setelah penyakit Human Immunodeficiency Virus (HIV) (Raisuli dkk, 2017). Menurut World Health Organization (WHO) 2020, TB disebabkan oleh Bakteri Tahan Asam (BTA) yaitu Mycobacterium tuberkulosis yang paling sering mempengaruhi paru. TB dapat disembuhkan dan dapat dicegah. TB tersebar dari orang ke orang melalui udara. Ketika orang dengan TB batuk, bersin atau meludah, mereka mendorong kuman TB ke udara. Seseorang dapat terinfeksi hanya dengan menghirup beberapa kuman Mycobacterium tuberculosis (Mtb). Sebanyak 1.500 .000 orang menderita TB pada tahun 2018 (termasuk 25.000 orang dengan HIV). Di seluruh dunia, TB adalah salah satu dari 10 penyebab utama kematian dan penyebab utama dari satu agen menular di atas HIV/AIDS.

Pada tahun 2018, berdasarkan data organisasi kesehatan dunia (WHO, 2019) jumlah kasus TB Indonesia berada di urutan ketiga terbesar dunia setelah India yang mencapai 2,6 juta kasus dan Tiongkok 866.000 kasus. Prevalensi TB BTA positif di Indonesia pada tahun 2018 adalah 845.000 kasus atau 316 per 100.000 penduduk. Sedangkan angka mortalitas pada tahun 2018 yaitu $12 \%$ dari total kasus. Kasus TB di Indonesia terbesar akibat merokok, kurang gizi, diabetes dan mengkonsumsi alkohol.

Berbagai upaya telah dilakukan pemerintah untuk menekan angka kesakitan dan kematian karena TB antara lain melalui strategi pengawasan langsung menelan obat jangka pendek setiap hari dengan nama strategi Directly Observed Treatment Shortcourse Chemoterapy (DOTS). Stategi ini terbukti cukup efektif dalam penyembuhan penderita di beberapa negara berkembang, termasuk Indonesia. Indikasinya, sejak strategi DOTS diperkenalkan pertama kali di Indonesia pada tahun 1995, angka kesembuhan telah mencapai 87\% pada tahun 2010. Angka ini melebihi target WHO yaitu $85 \%$ tapi sangat disayangkan bahwa pengetahuan penderita tentang pengobatan TB masih rendah sehingga dapat mempengaruhi kesembuhan penderita (Depkes RI, 2012).

Untuk mencapai kesembuhan diperlukan keteraturan atau kepatuhan berobat bagi setiap penderita. Panduan obat anti tuberkulosis jangka pendek dan penerapan pengawasan menelan 
obat merupakan strategi untuk menjamin kesembuhan penderita, walaupun obat yang digunakan baik tetapi bila penderita tidak berobat dengan teratur maka umumnya hasil pengobatan akan mengecewakan. Kenyataan lain bahwa penyakit TB sulit untuk disembuhkan karena obat yang diberikan harus beberapa macam sekaligus serta pengobatannya makan waktu lama, setidaknya 6 bulan sehingga menyebabkan penderita banyak yang putus berobat. Hal yang menjadi penyebabnya adalah kurangnya perhatian pada TB dari berbagai pihak terkait, akibatnya program penanggulangan TB di berbagai tempat menjadi amat lemah (Fitri, Marlindawani, \& Purba, 2018).

Diagnosis TB dapat ditegakkan berdasarkan gejala klinik, pemeriksaan fisik/jasmani, pemeriksaan bakteriologik, radiologik dan pemeriksaan penunjang lainnya. Pemeriksaan bakteriologik dapat dilakukan dengan cara mikroskopik dan biakan. Pemeriksaan dahak secara mikroskopis dengan pewarnaan BTA masih merupakan pemeriksaan standar diagnosis BTA, paling efisien, mudah dan murah, dan hampir semua unit laboratorium dapat melaksanakannya untuk mendukung diagnosis penyakit TB serta untuk menilai kemajuan pengobatan (Karunia Rambi, Makamina, Mamuay, \& Binambuni, 2017).

Di laboratorium Puskesmas Kota Kaler Sumedang dilakukan pemeriksaan TB dengan cara mikroskopis untuk melihat kemajuan pengobatan. Mekanisme pemeriksaan TB di Puskesmas Kota Kaler Sumedang yaitu pada saat pasien pertama melakukan pemeriksaan dan dinyatakan positif, pada saat bulan kedua setelah pengobatan, pada saat bulan kelima setelah pengobatan dan pada saat bulan ke enam pengobatan. Dengan latar belakang terebut maka pentingnya mengetahui gambaran mikroskopik Mycobacterium tuberculosis pada pasien yang menjalani pengobatan berdasarkan lamanya pengobatan, sehingga penulis tertarik untuk meneliti "Gambaran Mikroskopik Mycobacterium tuberculosis pada Pasien Tuberkulosis Di Puskesmas Kota Kaler Sumedang".

\section{METODE PENELITIAN}

Metode penelitian yang digunakan adalah metode deskriptif dengan mengolah data sekunder dari Puskesmas Kota Kaler Sumedang. Sampel dalam penelitian ini adalah data hasil pemeriksaan BTA pada pasien TB positif sebelum pengobatan hingga akhir pengobatan yang tercatat di medical record Puskesmas Kota Kaler Sumedang pada periode Januari-Desember 
2019. Teknik pengambilan sampel yang digunakan yaitu total sampling. Total sampling adalah cara pengambilan sampel dimana jumlah populasi keseluruhan diambil menjadi jumlah sampel. Sampel yang digunakan yaitu sebanyak 30 sampel. Data dianalisis secara statistika.

\section{HASIL DAN PEMBAHASAN}

Sesuai dengan hasil penelitian yang dilakukan di Puskesmas Kota Kaler Sumedang pada tanggal 18-30 Mei 2020, dengan sampel sebanyak 30 pasien. Tabel 1 menunjukkan distribusi frekuensi kuantitas $M t b$ pasien TB sebelum pengobatan.

Tabel 1. Distribusi Frekuensi Kuantitas Mycobakterium Tuberculosis Pasien Sebelum Pengobatan OAT

\begin{tabular}{|c|c|c|c|}
\hline No & $\begin{array}{l}\text { Gambaran Mikroskopik } \\
\text { Mycobacterium tuberculosis } \\
\text { Sebelum Pengobatan OAT }\end{array}$ & Frekuensi & $\begin{array}{l}\text { Presentase } \\
(\%)\end{array}$ \\
\hline 1 & +1 & 19 & 63,3 \\
\hline 2 & +2 & 2 & 6,7 \\
\hline 3 & +3 & 9 & 30 \\
\hline 4 & Scanty (1-9 BTA) & 0 & 0 \\
\hline 5 & $\operatorname{Neg}(-)$ & 0 & 0 \\
\hline \multicolumn{2}{|c|}{ Jumlah } & 30 & 100 \\
\hline
\end{tabular}

Berdasarkan tabel 5 diatas menunjukan bahwa dari 30 pasien, sebagian besar pasien atau penderita TB positif yang melakukan pemeriksaan dengan hasil +1 sebanyak 19 orang $(63,3 \%)$, sedangkan pada gambaran mikroskopik scanty (1-9 BTA) dan yang menunjukan hasil negatif () tidak ada.

Tabel 2. Distribusi Frekuensi Kuantitas Mycobakterium Tuberculosis Pasien Setelah Pengobatan OAT Selama 6 Bulan

\begin{tabular}{|c|c|c|c|}
\hline No & $\begin{array}{l}\text { Gambaran Mikroskopik } \\
\text { Mycobacterium tuberculosis } \\
\text { Sebelum Pengobatan OAT }\end{array}$ & Frekuensi & $\begin{array}{l}\text { Presentase } \\
(\%)\end{array}$ \\
\hline 1 & +1 & 0 & 0 \\
\hline 2 & +2 & 0 & 0 \\
\hline 3 & +3 & 0 & 0 \\
\hline 4 & Scanty (1-9 BTA) & 0 & 0 \\
\hline 5 & $\operatorname{Neg}(-)$ & 30 & 100 \\
\hline \multicolumn{2}{|c|}{ Jumlah } & 30 & 100 \\
\hline
\end{tabular}


Dari Tabel 1 diatas menunjukan bahwa dari 30 pasien setelah melakukan pengobatan selama enam bulan semua pasien menunjukan hasil baik yaitu negatif (-) atau tidak terdapat BTA pada sampel dahak pasien.Hasil penelitian mengenai penderita TB positif sebelum pengobatan, menunjukan bahwa dari 30 pasien di Puskesmas Kota Kaler Sumedang terdapat 19 orang $(63,3 \%)$ penderita TB positif satu $(+1)$ dan penderita TB positif dua $(+2) 2$ orang $(6,7 \%)$ sedangkan penderita atau pasien TB positif tiga ( +3$) 9$ orang $(30 \%)$. Sementara kategori scanty atau ditemukan 1-9 BTA dalam 1 lapang pandang dan negatif tidak ada. Dari hasil penelitian penderita TB positif sebelum pengobatan seluruhnya positif TB dengan gambaran mikroskopik Mycobacterium tuberculosis yaitu +1 sampai +3 hal ini dikarenakan pasien TB belum melakukan pengobatan.

Menurut Kemenkes RI 2013, pasien yang tidak diobati setelah lima tahun, 50\% akan meninggal, 25\% akan sembuh sendiri dengan daya tahan tubuh yang tinggi dan $25 \%$ akan menjadi kasus kronis yang tetap menular (Fitria \& Febriant, 2016). Pengobatan TB bertujuan untuk menyembuhkan penyakit pasien, mencegah kekambuhan, mencegah kematian, memutuskan mata rantai penularan, dan mencegah resistensi terhadap OAT (Maksum. R, 2015). Terapi utama untuk infeksi mycobakteri adalah kemo terapi spesifik. Diantara 1.000.000 dan satu di antara 100.000.000 basil TB adalah mutan spontan yang resisten terhadap obat anti TB lini pertama. Jika obat tersebut digunakan sendirian, basil TB resisten akan muncul dengan cepat dan berkembangbiak. Oleh sebab itu, panduan terapi menggunakan kombinasi beberapa obat untuk mencapai angka penyembuhan $>95 \%$ (Jawets. Dkk, 2012).

Menurut Kemenkes RI 2013, Pengobatan TB terbagi atas tahap awal (intensif) dan tahap lanjutan dimana OAT disediakan dalam bentuk paket untuk memudahkan pemberian obat dan menjamin kontinuitas pengobatan sampai selesai (satu paket untuk satu pasien dalam satu masa pengobatan) (Fitria \& Febriant, 2016). Pada tahap intensif (awal) penderita mendapat obat setiap hari dan diawasi langsung untuk mencegah terjadinya kekebalan terhadap semua OAT. Terutama rifampisin. Bila pengobatan tahap intensif diberikan secara tepat, biasanya penderita menular menjadi tidak menular dalam kurun waktu dua minggu sebagian besar penderita TB BTA positif menjadi BTA negatif (konversi) pada akhir pengobatan intensif (Maksum. R, 2015).

Dari hasil penelitian menunjukan bahwa dari 30 pasien penderita TB positif yang telah melakukan pengobatan bulan ke VI di Puskesmas Kota Kaler Sumedang. Semua pasien Open Journal System (OJS): journal.thamrin.ac.id 
dinyatakan negatif (-) sebanyak 30 pasien (100\%). Yang artinya pengobatan dilakukan secara tepat dan seluruh pasien dinyatakan sembuh. Penderita dinyatakan sembuh bila penderita telah menyelesaikan pengobatannya secara lengkap, dan pemeriksaan ulang dahak (follow up) paling sedikit 2 kali berturut-turut hasilnya negatif (yaitu pada AP dan/atau sebulan sebelum AP, dan pada satu pemeriksaan follow up sebelumnya) (Depkes RI 2012).

Menurut Kemenkes RI tahun 2012, ada banyak faktor yang dapat mempengaruhi keberhasilan pengobatan TB. Tinggi rendahnya TSR atau Treatment Success Rate dipengaruhi oleh beberapa faktor, antara lain; 1) Faktor pasien: pasien tidak patuh minum obat anti TB (OAT), pasien pindah fasilitas pelayanan kesehatan, dan TB nya termasuk yang resisten terhadap OAT. 2) Faktor pengawas minum obat (PMO): PMO tidak ada, PMO ada tapi kurang memantau. 3) Faktor obat: suplai OAT terganggu sehingga pasien menunda atau tidak meneruskan minum obat, dan kualitas OAT menurun karena penyimpanan tidak sesuai standar.

\section{SIMPULAN}

Gambaran mikroskopik Mycobacterium tuberculosis pada pasien TB sebelum melakukan pengobatan OAT di Puskesmas Kota Kaler Sumedang diperoleh hasil dari 30 pasien penderita TB positif sebelum pengobatan seluruhnya positif TB dengan hasil BTA $+1,+2$ dan +3 yang disebabkan karena belum melakukan pengobatan, sedangkan dari 30 pasien yang telah mengkonsumsi OAT selama 6 bulan seluruhnya dinyatakan sembuh dikarenakan pengobatan yang dilakukan secara tepat dan benar.

\section{REFERENSI}

Akmal. (2010). Ensiklopedia Kesehatan Untuk Umum. Yogyakarta : Ar-Ruzz Media

Andayani, S., \& Astuti, Y. (2017). Prediksi Kejadian Penyakit Tuberkolosis Paru Berdasarkan Usia di Kabupaten Ponorogo Tahun 2016-2020. Indonesian Journal for Health Sciences, 01(02), 29-33.

Depkes RI. 2012. Pedoman Nasional Penanggulangan Tuberkulosis. Jakarta.

Fitri, L. D., Marlindawani, J., \& Purba, A. (2018). Kepatuhan Minum Obat Pada Pasien Tuberkulosis Paru. Jurnal Ilmu Kesehatan Masyarakat, 07(01), 33-42. 
Fitria, R., \& Febriant, C. A. (2016). Hubungan Dukungan Keluarga Dengan Kepatuhan Minum Obat Pada Pasien Tuberkulosis Paru Di Wilayah Kerja Puskesmas Gading Rejo 2015. Jurnal Dunia Kesmas, 05(01), 24-31.

Kemenkes RI. (2009). Keputusan Menteri Kesehatan Republik Indonesia No 364/MENKES/SK/V/2009 Tentang Pedoman Penanggulangan Tuberkulosis. Jakarta

Maksum, (2015). Mekanisme Aksi Molekuler Antibiotik dan Kemoterapi. Penerbit Buku kedokteran. Jakarta: EGC

Raisuli. (2017). Karakteristik Penderita TB di Puskesmas Rujukan Mikroskopik Kabupaten Aceh Besar. SEL Jurnal Penelitian Kesehatan: Vol 4(1):13-20

Rambi, E. V., Makamina, M. A., Mamuay, T., \& Binambuni, L. (2017). Gambaran Mikroskopis Hasil Pemeriksaan Basil Tahan Asam (BTA) Menggunakan Teknik Konvensional Dan Teknik Sentrifugasi Sputum . Jurusan Analis Kesehatan Poltekkes Kemenkes Manado, 651-656.

Sondak, M., Porotu’o, J., \& Homent, H. (2016). Hasil Diagnostik Mycobacterium Tuberculosis Dari Sputum Penderita Batuk $\geq 2$ Minggun Dengan Pewarnaan Ziehl Neelsen Di Puskesmas Paniki Bawah, Tikala Baru Dan Wonasa Manado. Jurnal e-Biomedik (eBm), $4(1), 29-33$.

WHO. (2019). Global Tuberculosis report 2019. https://www. who.int/tb/global-report-2019. Widoyono. (2005). Penyakit Tropis Epidemiologi, Penularan. Pencegahan Dan Pemberantasanya Erlangga. Jakarta

Willar, S., Porotu'o, J., \& Waworuntu, O. (2016). Hasil diagnostik Mycobacterium tuberculosis SDGDSHQGHULWDEDWXN minggu dengan pewarnaan Ziehl-Neelsen di Puskesmas Bailang dan Puskesmas Bengkol Manado. Jurnal e-Biomedik, 4(2), 50-62.

World Health Organization (WHO). 2020. Tuberculosis. https://www.who.int/newsroom/fact-sheets/detail/tuberculosis. 